Article

\title{
Enhancement of Biomass and Lipid Productivities of Scenedesmus sp. Cultivated in the Wastewater of the Dairy Industry
}

\author{
Ingrid Mercado $\mathbb{D}^{D}$, Xavier Álvarez *(D), María-Eloiza Verduga and Andrea Cruz \\ Microbial Biotechnology Laboratory (BiotemLab), Faculty of Natural Sciences, Universidad de Guayaquil, \\ Guayaquil 471, Ecuador; ingrid.mercador@ug.edu.ec (I.M.); maria.verdugav@ug.edu.ec (M.-E.V.); \\ andrea.cruzp@ug.edu.ec (A.C.) \\ * Correspondence: xavier.alvarezmo@ug.edu.ec; Tel.: +59-39-9974-7397
}

Received: 13 September 2020; Accepted: 11 November 2020; Published: 14 November 2020

\begin{abstract}
Microalgae are photoautotrophic microorganisms capable of producing compounds with potential bioenergetic applications as an alternative energy source due to the imminent exhaustion of fossil fuels, their impact on the environment, and the constant population increase. The mass cultivation of these microorganisms requires high concentrations of nutrients, which is not profitable if analytical grade culture media are used. A viable alternative is the use of agro-industrial wastewater, due to the metabolic flexibility of these microorganisms and their ability to take advantage of the nutrients present in these substrates. For the reasons mentioned above, the effect of the cultivation in wastewater from cheese processing on the growth parameters and biomass composition of Scenedesmus sp. was evaluated, and its nutrient removal capacity determined. A high lipid concentration was obtained in the cultures with the dairy effluent $\left(507.81 \pm 19.09 \mathrm{mg} \mathrm{g}^{-1}\right)$ compared to the standard culture medium, while the growth parameters remained similar to the control medium. Scenedesmus sp. achieved high percentages of nutrient assimilation of the wastewater used $(88.41 \%$ and $97.07 \%$ for nitrogen and phosphorus, respectively). With the results obtained, the feasibility of cultivating microalgae in agro-industrial wastewater as an alternative culture medium that induces the accumulation of compounds with potential bioenergetic applications was verified.
\end{abstract}

Keywords: Scenedesmus sp.; microalgae; wastewater; lipid production; nutrient removal

\section{Introduction}

Fossil fuels are hydrocarbons generated millions of years ago that appear in solid (coal), liquid (oil), or gaseous (natural gas) forms, which come from the decomposition of organic matter [1,2]. These molecules are responsible for $86 \%$ of the energy produced worldwide [3]. However, they are the primary source of greenhouse gas emissions [4], making their use unsustainable. Due to their environmental impact, imminent depletion (40-60 years), and the increase in world energy demand ( $\uparrow 50 \%$ by 2030 ), other sustainable energy sources are being sought, such as solar, tidal, and biofuels, among others, considered as clean energies [5-7].

The latter comprise any fuel derived from biomass or its residues such as plants, animals, or microorganisms. Biofuels emerge as a profitable alternative to the regular consumption of fossil fuels; the most developed are bioethanol, biodiesel, and biogas, whose consumption reduces carbon emissions by between $30 \%$ and 50\%. Biomethanol, bioethers, synthetic biofuels, biohydrogen, and vegetable oils are used less frequently [8]. The use of biofuels for energy production has many advantages; however, only $10 \%$ of the energy is obtained from biomass and waste [9]. These bioenergetic compounds include liquid, solid, and gaseous fuels [8] classified according to the source of production in the first, second, third, and fourth generation. 
First-generation biofuels are produced from food or edible vegetable oils ( $>90 \%$ of the biodiesel produced worldwide) such as rapeseed, soybeans, sunflower, and palm, which are readily available crops. However, their mass production is not profitable due to the high costs of biodiesel production and competition with other important food crops for land use [10]. Second-generation biofuels are produced from agricultural residues (residual vegetable oil, straw, rice husk), forestry (wood, wood chips), and industrial and non-food crops, which require less land and water and reduce the problems of deforestation. Despite this, they are not abundant enough to cover world energy demand [11]. Third-generation biofuels are produced from algae and microorganisms such as bacteria, yeasts, cyanobacteria, and microalgae, which have higher yields than other biofuels (10 times more) and help in the consumption of atmospheric $\mathrm{CO}_{2}$, reducing environmental problems [12]. Biofuels produced by algae are profitable due to their high-efficiency rates (yield greater than $98,000 \mathrm{~L} \mathrm{ha}^{-1}$ of biodiesel), they can supply a large part of the energy demand, they do not compromise food security, can be grown quickly (high growth rates), they are not toxic, and their cultivation does not need arable land $[7,13]$.

Finally, fourth-generation biofuels result from the modification of photosynthetic microorganisms based on metabolic engineering, allowing easy extraction of microbial products, simplifying production stages, cost reduction, and performance improvement. Currently, the genetic manipulation of these microorganisms, such as microalgae, seeks a directed improvement of cellular activity that allows the generation of added value by-products, increasing the profitability of the process [14,15]. Microalgae have been prioritized as potential biofuel producers because they achieve yields between 15 and 300 times more than a traditional agricultural crop [7].

Microalgae can present with a eukaryotic cell organization (Chlorophyta, Bacillariophyta, Dinoflagellata) or prokaryote (Cyanophyta); however, cyanobacteria are not strictly within this classification, but they are considered for their high economic value. Microalgae can capture light energy and use it in organic molecules such as proteins, carbohydrates, or lipids through photosynthesis [16,17]. The cultivation of these microorganisms presents excellent advantages, such as high growth rates, high productivity, no requirement of agricultural land for their cultivation, short harvest cycles, ease of cultivation (few nutritional, environmental, and operational requirements), high lipid content, and high photosynthetic efficiency (4 times higher than plants). They are an inexhaustible-renewable resource, among others $[18,19]$. They also fulfill ecological functions such as global carbon sequestration $(1.8 \mathrm{~kg}$ of $\mathrm{CO}_{2} \mathrm{~kg}^{-1}$ of dry biomass), fixation of atmospheric nitrogen, and production of more than $50 \%$ of global oxygen [17-19].

These microorganisms constitute a potential source of biomass for the production of different types of biofuels. In addition, they contain between $20 \%$ and $50 \%$ lipids (under stress conditions) in terms of the dry weight of the biomass [20]. Microalgal biomass production is assumed to be between 15 and $25 \mathrm{t} \mathrm{ha}^{-1}$ year $^{-1}$, which would correspond to 4.5 and $7.5 \mathrm{t} \mathrm{ha}^{-1}$ year $^{-1}$ of lipid production (cellular lipid percentage of 30\%) [21]. In this way, current studies seek to intensify the growth rate and production of lipids. Microalgae, under stress conditions, can accumulate lipids and carbohydrates in higher concentrations, decreasing protein synthesis [22]. Some of the stress conditions evaluated are limitation of nutrients such as $\mathrm{N}, \mathrm{P}$, or $\mathrm{S}$ (C becomes triglycerides or fatty acids), the addition of metal ions $\left(\mathrm{Fe}^{+3}, \mathrm{Mg}^{+2}, \mathrm{Ca}^{+2}\right)$, the addition of salts (EDTA), increase or decrease in light intensity, temperature, $\mathrm{pH}$, and radiation $[23,24]$.

The cultivation of these microorganisms on a large scale to obtain various metabolites of commercial interest generates a high demand for freshwater and nutrients, usually supplemented by chemically synthesized fertilizers due to the lower cost they present in relation to nutrients from formulated cultivation. However, industrial production with fertilizers is not profitable $\left(>\$ 400 \mathrm{t}^{-1}\right)$ if the costs of biomass production and processing are taken into account in the production of biofuels [25]. The use of agro-industrial wastewater emerges as a viable alternative in the cultivation of microalgae and cyanobacteria due to their outstanding capacity to adapt to various water bodies as sources of fresh, marine, brackish, and waste water, among others [26,27]. In this way, microalgae cultivation in 
wastewater is a profitable, highly productive, and ecological process (decreased eutrophication that causes low oxygen levels and contamination in freshwater bodies) [28,29].

Due to the advantages mentioned above, the cultivation of Scenedesmus sp. in wastewater from dairy industries is proposed in this study, evaluating mainly the production of lipids and carbohydrates. The growth, productivity, and biochemical composition of the biomass and the removal of nutrients by Scenedesmus sp. will also be determined.

This investigation was carried out to induce an increase in the lipid and carbohydrate content in the biomass of the microalgae Scenedesmus sp. using wastewater as a cultivation substrate for the production of metabolites of bioenergetic interest, and at the same time cleaning it, avoiding the serious environmental problems caused by wastewater being directly discharged into the water bodies.

\section{Materials and Methods}

\subsection{Microorganism and Wastewater Characteristics}

The microalgae Scenedesmus sp. (Figure 1) evaluated in this research was obtained from the Bank of microalgae and cyanobacterial strains of the Laboratorio de Biotecnología Microbiana (BiotemLab) of the Universidad de Guayaquil (Universidad de Guayaquil, Guayaquil, Guayas, Ecuador), coded as RJ 3009 and conserved in solid BG11 standard medium [30] at a temperature of $20 \pm 2{ }^{\circ} \mathrm{C}$, light intensity of $100.0 \mu \mathrm{mol}$ photon $\mathrm{m}^{-2} \mathrm{~s}^{-1}$, and photoperiod $12 \mathrm{~h} \mathrm{light} / 12 \mathrm{~h}$ dark. Cultures of Scenedesmus sp. were acclimated to dairy industry wastewater by gradually adding increasing concentrations of cheese processing wastewater over several months, with an initial concentration of $10 \%$.

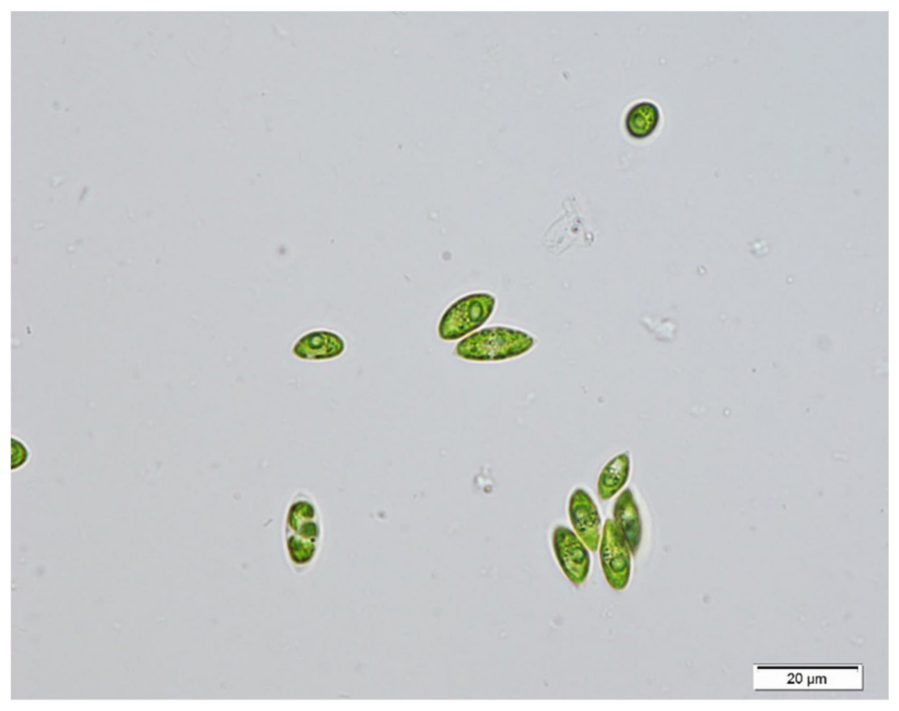

Figure 1. Light microscopic images (60x) of Scenedesmus sp.

The wastewater used as a culture medium was obtained from a dairy industry that produces cheeses and lactic derivatives. The dairy industry wastewater used in this research (DIWW) had the following characteristics: $2.22 \mathrm{mM}$ total nitrogen (TN), $0.20 \mathrm{mM}$ phosphate, $5.5 \mathrm{pH}, 3500 \mathrm{mg} \mathrm{O}_{2} \mathrm{~L}^{-1}$ chemical oxygen demand (COD), and heavy metal concentrations less than $0.09 \mathrm{mg} \mathrm{L}^{-1}$, as shown in Table 1. 
Table 1. Chemical characteristics of the dairy industry wastewater (DIWW).

\begin{tabular}{cc}
\hline Parameter & Value \\
\hline $\mathrm{TN}$ & $2.22 \mathrm{mM}$ \\
$\mathrm{PO}_{4}{ }^{3-}$ & $0.20 \mathrm{mM}$ \\
$\mathrm{pH}$ & 5.5 \\
$\mathrm{COD}$ & $3500 \mathrm{mg} \mathrm{O}_{2} \mathrm{~L}^{-1}$ \\
$\mathrm{As}$ & $0.0060 \mathrm{mg} \mathrm{L}^{-1}$ \\
$\mathrm{Cd}$ & $0.00047 \mathrm{mg} \mathrm{L}^{-1}$ \\
$\mathrm{Hg}$ & $0.0890 \mathrm{mg} \mathrm{L}^{-1}$ \\
$\mathrm{~Pb}$ & $0.0001 \mathrm{mg} \mathrm{L}^{-1}$ \\
\hline
\end{tabular}

\subsection{Culture Conditions}

Scenedesmus sp. was cultivated in batch in triplicate in $150 \mathrm{~mL}$ photobioreactors (PBR) under a circadian illumination regime of $12 \mathrm{~h}$ light $/ 12 \mathrm{~h}$ dark with a temperature of $30{ }^{\circ} \mathrm{C}$ (Figure 2), light intensity of $100.0 \mu \mathrm{mol}$ photon $\mathrm{m}^{-2} \mathrm{~s}^{-1}$, and a continuous supply of $\mathrm{CO}_{2}$ pulses $(1.5 \% \mathrm{v} / \mathrm{v})$ to keep the $\mathrm{pH}$ stable $(7.2 \pm 0.2)$ and as a carbon source [31]. The cultures were inoculated with a concentration of $1.5 \times 10^{7}$ cell $\mathrm{mL}^{-1}$.

For the control, the culture medium BG11 with the following composition was used: $\mathrm{NaNO}_{3}$ $17.65 \mathrm{Mm}, \mathrm{K}_{2} \mathrm{HPO}_{4} 0.23 \mathrm{mM}, \mathrm{MgSO}_{4} \cdot 7 \mathrm{H}_{2} \mathrm{O} 0.30 \mathrm{mM}, \mathrm{CaCl}_{2} \cdot \mathrm{H}_{2} \mathrm{O} 0.25 \mathrm{mM}$, citric acid $0.03 \mathrm{mM}$, ferric ammonium citrate $0.03 \mathrm{mM}$, EDTA $0.003 \mathrm{mM}, \mathrm{Na}_{2} \mathrm{CO}_{3} 0.38 \mathrm{mM}, \mathrm{H}_{3} \mathrm{BO}_{3} 0.046 \mathrm{mM}$, $\mathrm{MnCl}_{2} \cdot 4 \mathrm{H}_{2} \mathrm{O} 0.009 \mathrm{mM}, \mathrm{ZnSO}_{4} \cdot 7 \mathrm{H}_{2} \mathrm{O} 0.0008 \mathrm{mM}, \mathrm{Na}_{2} \mathrm{MoO}_{4} \cdot 2 \mathrm{H}_{2} \mathrm{O} 0.0016 \mathrm{mM}, \mathrm{CuSO}_{4} \cdot 5 \mathrm{H}_{2} \mathrm{O} 0.0003 \mathrm{mM}$, and $\mathrm{Co}\left(\mathrm{NO}_{3}\right)_{2} \cdot 6 \mathrm{H}_{2} \mathrm{O} 0.0002 \mathrm{mM}$.

For the treatments, $100 \%$ dairy wastewater (DIWW) was used with a nutritional correction with the commercial fertilizer Bayfolan ${ }^{\circledR}$ (Bayer, Valencia, Spain) reaching a concentration of $20.80 \mathrm{mM}$ of total nitrogen and $1.67 \mathrm{mM}$ of $\mathrm{PO}_{4}{ }^{3-}$.

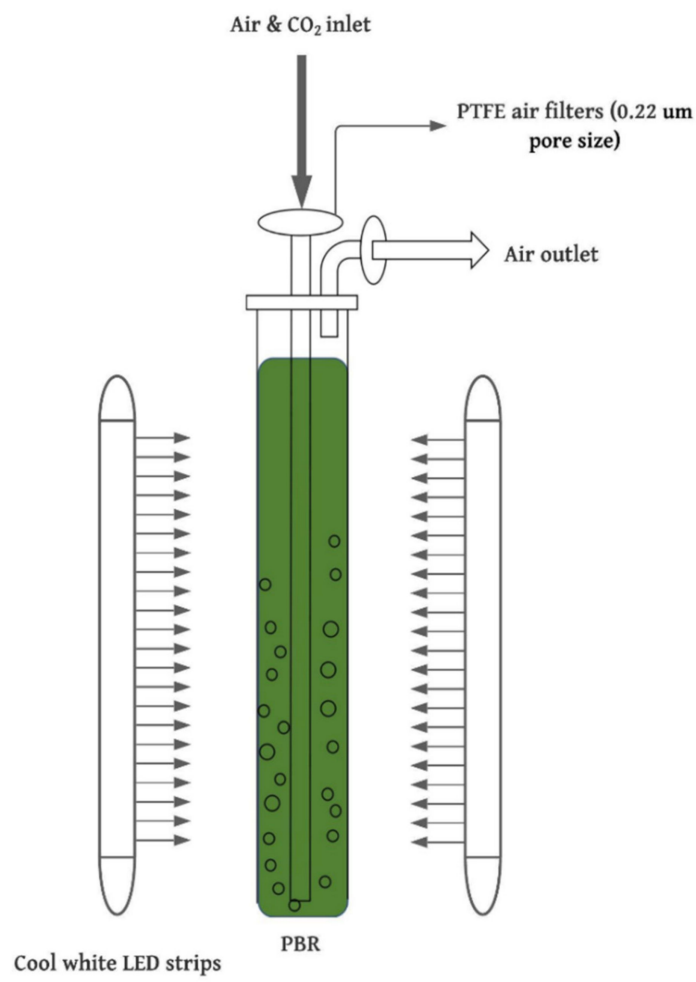

Figure 2. Schematic diagram of the $150 \mathrm{~mL}$ lab-scale photobioreactor (PBR), used for Scenedesmus sp. cultivation. The air and $\mathrm{CO}_{2}$ inlet and air outlet were equipped with $0.22 \mu \mathrm{m}$ PTFE (Polytetrafluoroethylene) filters (Sigma-Aldrich, Saint Louis, MO, USA). 


\subsection{Determination of Growth Parameters}

Growth was evaluated by cell concentration (cell $\mathrm{mL}^{-1}$ ) every $24 \mathrm{~h}$ : $10 \mathrm{uL}$ of culture was introduced into a Neubauer chamber, and cells from all squares were quantified in the central area.

Cell concentration was calculated using the following equation [32]:

$$
\mathrm{C}=\mathrm{N} \times 10^{4} \times f
$$

where $C$ is the cell concentration (cell $\mathrm{mL}^{-1}$ ), $\mathrm{N}$ the total number of cells counted in the area, and $f$ the dilution factor.

The specific growth rate $\left(\mu: \mathrm{day}^{-1}\right)$ was determined at the end of the assay based on the values obtained from the cell concentration using the equation proposed by Arredondo et al. [33]:

$$
\mu=\ln \left(\mathrm{N}_{2}-\mathrm{N}_{1}\right) / \mathrm{t}_{2}-\mathrm{t}_{1}
$$

where $\mathrm{N}_{1}$ and $\mathrm{N}_{2}$ are the cell density values at times $\mathrm{t}_{1}$ and $\mathrm{t}_{2}$, respectively.

The dry biomass weight was determined using the protocol proposed by Zhu and Lee [34], which consists of the use of fiberglass filters of $47 \mathrm{~mm}$ diameter and a pore diameter of $0.7 \mu \mathrm{m}$ (Whatman ${ }^{\circledR}$ GF/F). Previously, the filters were dried at $90{ }^{\circ} \mathrm{C}$ for $24 \mathrm{~h}$ in an oven, placed in a desiccator with $\mathrm{SiO}_{2}$ to avoid humidity, and weighed on an analytical balance. $5 \mathrm{~mL}$ of Scenedesmus sp. culture was filtered with the addition of $0.5 \mathrm{mM}$ ammonium formate $\left(\mathrm{HCO}_{2} \mathrm{NH}_{4}\right)$ to remove the salts from the culture medium and the wastewater. The biomass filters were dried at $80{ }^{\circ} \mathrm{C}$ for $24 \mathrm{~h}$ and weighed on an analytical balance. The dry weight corresponds to the difference between the weight of the filter with the dry biomass and the weight of the dry filter. In addition, the dry weight value of the suspended solids in the wastewater was subtracted. The biomass productivity $\left(\mathrm{g} \mathrm{L}^{-1}\right.$ day $\left.^{-1}\right)$ was calculated using the following equation:

$$
\mathrm{Pb}=\left(\mathrm{X}_{2}-\mathrm{X}_{1}\right) / \mathrm{t}_{2}-\mathrm{t}_{1}
$$

where $X_{1}$ and $X_{2}$ were the biomass concentrations $\left(\mathrm{g} \mathrm{L}^{-1}\right)$ on days $t_{1}$ (start of assay) and $t_{2}$ (end of the assay).

\subsection{Determination of Biochemical Composition}

The concentration of carbohydrates in the biomass was carried out by the Sulfuric Phenol method proposed by Dubois et al. [35]: $1 \mathrm{~mL}$ of centrifuged culture was used. The pellet was re-suspended in $1 \mathrm{~mL}$ of $1 \mathrm{~N} \mathrm{NaOH}$. The pellet was shaken in the vortex, sonicated at $20 \mathrm{kHz}$ and $4{ }^{\circ} \mathrm{C}$ for $20 \mathrm{~min}$ and centrifuged at $17,100 \times \mathrm{g}, 4^{\circ} \mathrm{C}$ for $15 \mathrm{~min}$. From the obtained supernatant, $100 \mu \mathrm{L}$ of each sample was transferred in triplicate, and $900 \mu \mathrm{L}$ of distilled water, $25 \mu \mathrm{L}$ of $80 \%$ phenol, and $2.5 \mathrm{~mL}$ of concentrated $\mathrm{H}_{2} \mathrm{SO}_{4}$ were added and shaken in the vortex. It was allowed to cool to room temperature for $30 \mathrm{~min}$ and was measured by spectrophotometry at $485 \mathrm{~nm}$, using glucose as standard.

The protein content of the biomass was determined by the protocol of Lowry et al. [36] modified by Herbert et al. [37], where $2 \mathrm{~mL}$ of $1 \mathrm{~N} \mathrm{NaOH}$ are added to $6 \mathrm{mg}$ of dry biomass, sonicated at $20 \mathrm{kHz}$ and $4{ }^{\circ} \mathrm{C}$ for $15 \mathrm{~min}$, followed by a water bath at $95-100{ }^{\circ} \mathrm{C}$ for $45 \mathrm{~min}$. All samples were allowed to cool to room temperature and centrifuged at $17,100 \times g$ and $4{ }^{\circ} \mathrm{C}$ for $15 \mathrm{~min}$. From the obtained supernatant, $100 \mu \mathrm{L}$ of each sample was transferred in triplicate, $400 \mu \mathrm{L}$ of distilled water, $300 \mu \mathrm{L}$ of $1 \mathrm{~N}$ $\mathrm{NaOH}$, and $2 \mathrm{~mL}$ of saturated $\mathrm{Cu}$-Tartrate solution were added, then it was mixed in the vortex and $10 \mathrm{~min}$ of reaction was expected. $400 \mu \mathrm{L}$ of Folin Ciocalteu diluted $v / v$ was added and left for $30 \mathrm{~min}$ at room temperature. Protein concentration was measured by spectrophotometry at $750 \mathrm{~nm}$, using bovine serum albumin as standard.

The lipid concentration of the biomass was determined by the method of Bligh and Dyer [38]: $3 \mathrm{~mL}$ of methanol and $1.5 \mathrm{~mL}$ of chloroform $v / v$ in a 2: 1 ratio were added to $5 \mathrm{mg}$ of dry biomass. It was then sonicated at $4{ }^{\circ} \mathrm{C}$ at $20 \mathrm{kHz}$ for $20 \mathrm{~min}$, followed by a water bath at $50{ }^{\circ} \mathrm{C}$ for $30 \mathrm{~min}$. The samples were allowed to cool to room temperature and centrifuged at $17,100 \times \mathrm{g}$ and $4{ }^{\circ} \mathrm{C}$ for $10 \mathrm{~min} .1 .5 \mathrm{~mL}$ 
of chloroform and $1.5 \mathrm{~mL}$ of distilled water were added to the supernatant and shaken in the vortex. It was centrifuged again at $17,100 \times g$ and $4{ }^{\circ} \mathrm{C}$ for $5 \mathrm{~min}$. To the organic phase previously separated from the upper aqueous phase, $0.5 \mathrm{~mL}$ of acetone was added (remaining substances were removed), evaporated with a nitrogen flow, and re-suspended in $1 \mathrm{~mL}$ of chloroform. The lipid concentration was determined by spectrophotometry using the Marsh and Weinstein [39] simple carbonization method: $100 \mu \mathrm{L}$ of each re-suspended sample was transferred in triplicate to glass tubes, $2.5 \mathrm{~mL}$ of concentrated $\mathrm{H}_{2} \mathrm{SO}_{4}$ was added, and it was brought to carbonization $\left(20{ }^{\circ} \mathrm{C}, 15 \mathrm{~min}\right)$. Finally, the tubes were allowed to cool to room temperature, and $3 \mathrm{~mL}$ of distilled water was added, to determine the absorbance at $375 \mathrm{~nm}$ by spectrophotometry, using palmitic acid as standard.

\subsection{Determination of the Lipid Profile}

The fatty acid methyl esters (FAMEs) profile of Scenedesmus sp. grown in dairy wastewater was determined using the following methodologies: fat content by the extraction method with a mixture of ethers (Method 989.05) from AOAC [40], concentration and composition of saturated fatty acids (myristic, palmitic, stearic, arachidic), monounsaturated (oleic) and polyunsaturated (linoleic, linolenic, EPA, DHA) by AOAC Method 963.22 [41] by gas chromatography and the content of trans fats by AOAC Method 996.06 [42] which involves the use of gas chromatography after extraction with acid/alkaline hydrolysis and mixed ethers.

\subsection{Nutrient Removal and Wastewater Characterization}

The total nitrogen concentration was determined by an adaptation of the persulfate digestion method proposed by D'Elia and Steudler [43], and the $\mathrm{PO}_{4}{ }^{3-}$ content by the vanadate-molybdate method of Tandon et al. [44]. These concentrations were measured by the Lovibond MD600/MaxiDirect photometer (Lovibond ${ }^{\circledR}$, Dortmund, North Rhine-Westphalia, Germany) based on the established protocols.

The characterization of the wastewater used in the test was carried out by determining the $\mathrm{pH}$, chemical oxygen demand (COD), and the concentration of $\mathrm{TN}, \mathrm{PO}_{4}{ }^{3-}$, and heavy metals $(\mathrm{As}, \mathrm{Cd}, \mathrm{Hg}, \mathrm{Pb})$. The COD expressed in $\mathrm{mg} \mathrm{O}_{2} \mathrm{~L}^{-1}$ was determined by an adaptation of the dichromate- $\mathrm{H}_{2} \mathrm{SO}_{4}$ method of APHA [45] measured by the Lovibond MD600 photometer based on respective protocols (Method M132). Mercury concentration was determined by applying the Evans, Johnson, and Leah protocol [46] by hot plate digestion with concentrated $\mathrm{HNO}_{3}$ and cold vapor atomic absorption spectrophotometry. Cadmium and lead were determined following AOAC Method 999.10 [47], using microwave digestion with $\mathrm{HNO}_{3}$ and $\mathrm{H}_{2} \mathrm{O}_{2}$ under pressure followed by atomic absorption spectroscopy in a graphite furnace. The arsenic concentration was determined using the programmed three-stage digestion technique with $\mathrm{HNO}_{3}$ and atomic absorption spectrophotometry with a graphite furnace [48].

The assimilation of nutrients and COD removal were calculated using the percentage difference between the concentrations of nitrogen, $\mathrm{PO}_{4}{ }^{3-}$, and $\mathrm{COD}$ at the beginning and end of the assay (supernatant).

\subsection{Morphological Changes}

Cell size measurements (length, width) were made with Digital Image System Software (Digital Imaging Systems ${ }^{\circledR}$, Buckinghamshire, England) while cell area and volume were determined by applying the following equations [49]:

$$
\begin{aligned}
& \mathrm{A}=\pi \mathrm{r} 1 \mathrm{r} 2 \\
& \mathrm{~V}=\pi \mathrm{a}^{2} \mathrm{~b} / 3
\end{aligned}
$$

where $\mathrm{r} 1$ and $\mathrm{r} 2$ correspond to half of the values of length and width of the cell (a: length $\mathrm{b}$ : width).

\subsection{Statistic Analysis}

The statistical and graphical analyses were conducted using Prism program version 8.3.0. (GraphPad Software, Inc ${ }^{\circledR}$, San Diego, CA, USA). All the data obtained when evaluating the differences 
between the control and the treatments were analyzed using one-way analysis of variance (ANOVA) and post hoc Tukey multiple comparisons test with a significance level of $95 \%(p \leq 0.05)$.

\section{Results}

The current demand for bioenergy generation that is clean, profitable, and productive has increased the study of microorganisms to produce compounds for energetic use such as bioethanol, biodiesel, biogas, among others. To achieve the research objectives, growth was determined by the daily cell density during the 11 days of culture and the dry weight of the biomass. At the end of the process, the biochemical composition of the biomass was evaluated to determine the increase in metabolites for bioenergetic applications.

\subsection{Determination of Growth Parameters}

The culture of Scenedesmus sp. for 11 days is shown in Figure 3, where the maximum cell density reached by the culture at $100 \%$ dairy industry wastewater is observed $\left(4.4 \times 10^{7} \pm 1.4 \times 10^{6}\right.$ cells $\mathrm{mL}^{-1}$ ). These results did not register significant differences from the controls where a maximum cell concentration of $4.3 \times 10^{7} \pm 3.4 \times 10^{6}$ cells mL $\mathrm{mL}^{-1}$ was obtained. These are expected results since the stress to which the microalgae were subjected to wastewater culture reduces cell growth. However, the results obtained when calculating the specific growth rate did show significant differences between controls and treatments, with $0.51 \pm 0.06$ day $^{-1}$ and $0.54 \pm 0.14$ day $^{-1}$, respectively, as shown in Figure 4 .

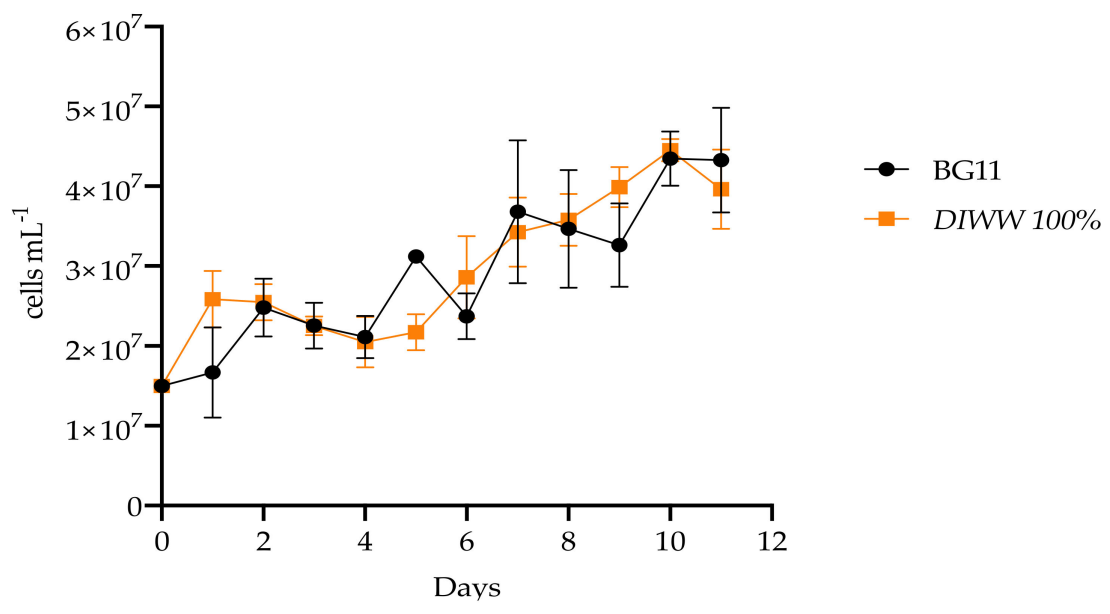

Figure 3. Cell density of the batch culture of Scenedesmus sp. in BG11 standard medium and dairy industry wastewater $(n=3)$.

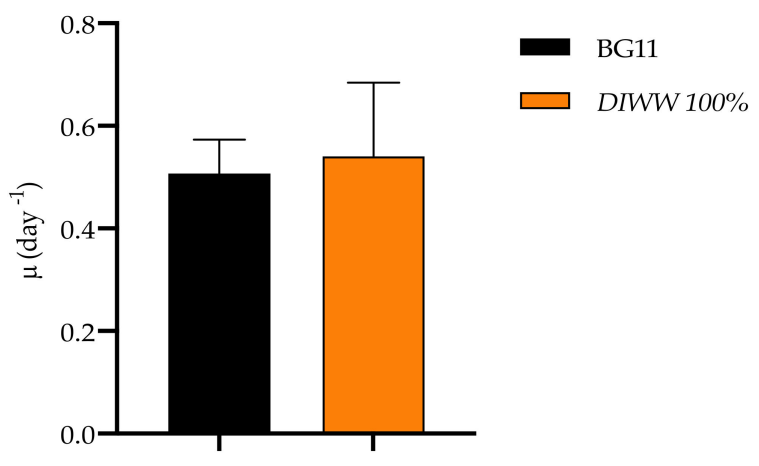

Figure 4. Specific growth rate of Scenedesmus sp. obtained in standard BG11 culture medium compared to the medium with the dairy industry wastewater $(n=3)$. 
The biomass productivity determined based on the dry weight data does not show significant differences between controls and treatments with $1.84 \pm 0.93 \mathrm{~g} \mathrm{~L}^{-1}$ day $^{-1}$ and $1.75 \pm 0.60 \mathrm{~g} \mathrm{~L}^{-1} \mathrm{day}^{-1}$, respectively (Table 2, Figure 5).

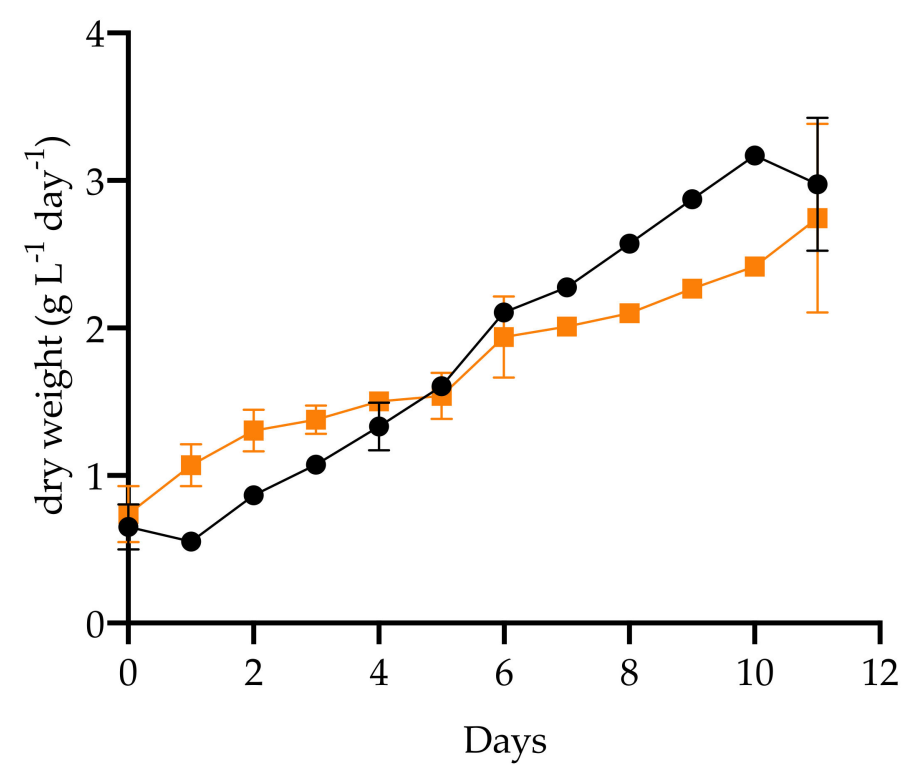

$\rightarrow$ BG11

- DIWW $100 \%$

Figure 5. Biomass productivity obtained with Scenedesmus sp. in BG11 culture medium and wastewater from the dairy industry $(n=3)$.

Table 2. Kinetic parameters of Scenedesmus sp. grown in batch for 11 days of cultivation. $\mathrm{X}_{\mathrm{m}}$ : maximum cell concentration obtained. $\mu$ : specific growth rate. $Q_{\mathrm{x}}$ : biomass productivity.

\begin{tabular}{cccc}
\hline Culture Medium & $\mathbf{X}_{\mathbf{m}}\left(\right.$ Cell $\left.\mathbf{~ L L}^{-\mathbf{1}}\right)$ & $\boldsymbol{\mu}$ day $\left.^{-\mathbf{1}}\right)$ & $\mathbf{Q}_{\mathbf{x}}\left(\mathbf{g ~ L}^{\mathbf{- 1}}\right.$ day $\left.^{\mathbf{- 1}}\right)$ \\
\hline BG11 & $4.3 \times 10^{7} \pm 3.4 \times 10^{6}$ & $0.51 \pm 0.06$ & $1.84 \pm 0.93$ \\
DIWW 100\% & $4.4 \times 10^{7} \pm 1.4 \times 10^{6}$ & $0.54 \pm 0.14$ & $1.75 \pm 0.60$ \\
\hline
\end{tabular}

\subsection{Determination of the Composition of Biomass}

Microalgae in standard growth conditions are characterized by lipid concentrations of $10-30 \%$ and carbohydrates of $5-30 \%$ of their composition [50], making them potential candidates to produce these compounds under stress conditions that induce their increase.

In this research, the cultivation of Scenedesmus sp. in dairy industry wastewater (DIWW) gave promising results compared to the standard BG11 culture medium in terms of compounds with potential use in bioenergy, reaching values of $276.96 \pm 20.46 \mathrm{mg} \mathrm{g}^{-1}$ for proteins, $304.09 \pm 31.65 \mathrm{mg} \mathrm{g}^{-1}$ for carbohydrates, and $350.81 \pm 33.05 \mathrm{mg} \mathrm{g}^{-1}$ for lipids in the control; and $198.36 \pm 12.73 \mathrm{mg} \mathrm{g}^{-1}$ for protein concentration, $268.51 \pm 24.52 \mathrm{mg} \mathrm{g}^{-1}$ for carbohydrates, and $507.81 \pm 19.09 \mathrm{mg} \mathrm{g}^{-1}$ for lipid production in the treatment. These values indicate that the biomass of Scenedesmus sp. cultivated in dairy industry wastewater reaches approximate percentages of $20 \%, 27 \%$, and $51 \%$ of proteins, carbohydrates, and lipids, respectively.

These results show that the biomass composition of Scenedesmus sp. is modified when cultivated in dairy effluents, a substrate that acts as a physiological stress factor since it tends to increase lipid concentrations and decrease protein content as shown in Figure 6. 


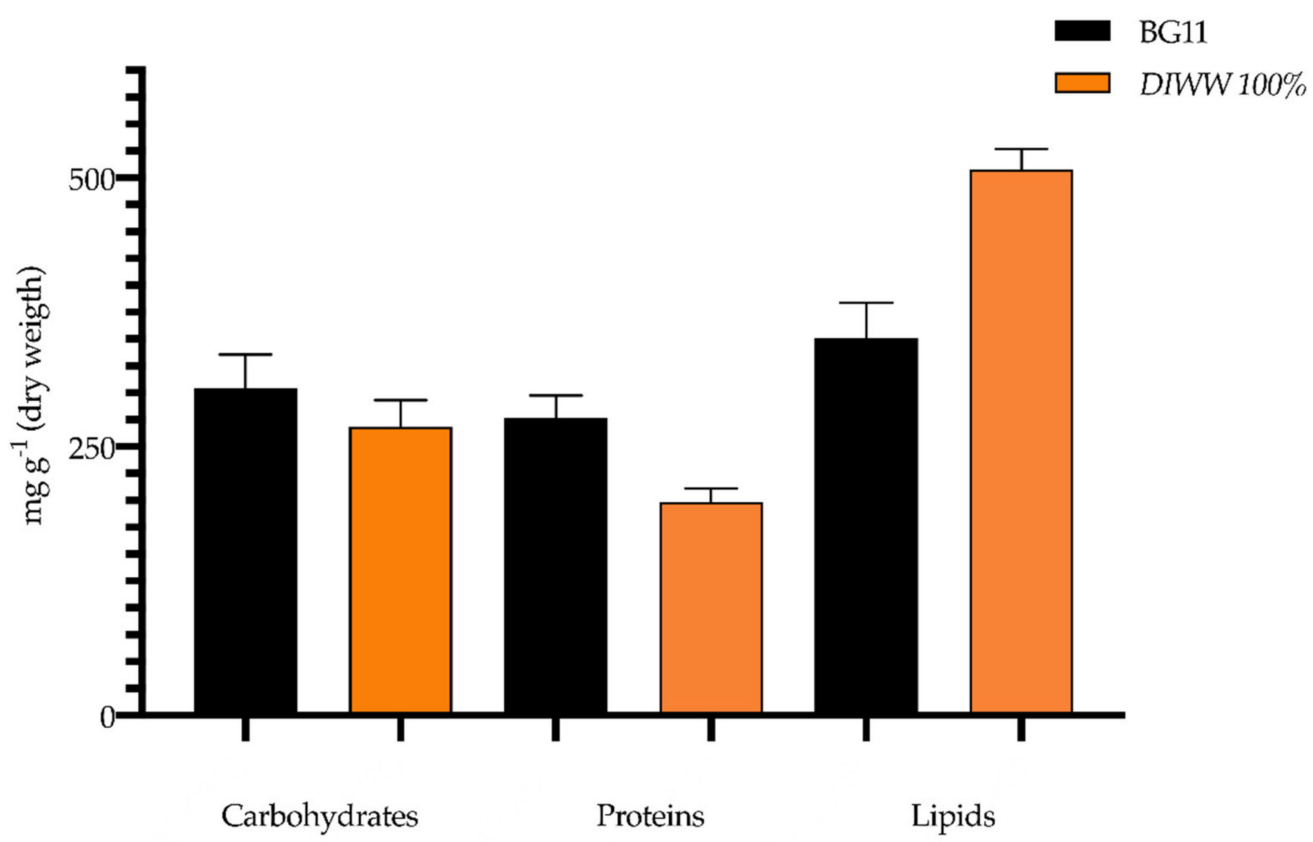

Figure 6. Biomass composition of Scenedesmus sp. grown in standard BG11 culture medium and dairy industry wastewater $(\mathrm{n}=3)$.

\subsection{Determination of the Lipid Profile}

The analysis of fatty acid methyl esters (FAMEs) produced by Scenedesmus sp. (RJ 3009) grown in dairy effluents shows dominance of polyunsaturated fatty acids (44\%), followed by saturated fatty acids $(29 \%)$ and, in a lower concentration, fatty acids monounsaturated $(21 \%)$. A higher proportion of linolenic, linoleic, and palmitic acid was obtained: $24 \%, 20 \%$, and $19 \%$ of the total lipid profile, respectively (See Table 3).

Table 3. Fatty acid composition of Scenedesmus sp. grown in $100 \%$ dairy industry wastewater.

\begin{tabular}{cc}
\hline Fatty Acid Methyl Esters (FAMEs) & \% Total Fatty Acids \\
\hline Saturated Fatty Acids \\
\hline Myristic (C14:0) \\
Palmitic (C16:0) \\
Stearic (C18:0) \\
Arachidic (C20:0) \\
Monounsaturated Fatty Acids \\
\hline Oleic (C18:1) \\
\hline Polyunsaturated Fatty Acids \\
\hline Linoleic (C18:2) \\
Linolenic (C18:3) \\
\hline Eicosapentaenoic (EPA) (C20:5) \\
Docosahexaenoic (DHA) (C18:3) \\
Total saturated fatty acids \\
Total monounsaturated fatty acids \\
Total polyunsaturated fatty acids \\
Trans fat \\
\hline
\end{tabular}




\subsection{Morphological Changes}

The culture in the dairy industry wastewater caused a substrate-induced modification in the size of the cells compared to the control. The same was observed concerning the area and cell volume (see Table 4).

Table 4. Cell morphological changes in Scenedesmus sp. in cultures with dairy wastewater compared to standard medium BG11.

\begin{tabular}{ccccc}
\hline Culture Medium & Length $(\boldsymbol{\mu m})$ & Width $(\mu \mathrm{m})$ & Area $\left(\boldsymbol{\mu m}^{\mathbf{2}}\right)$ & Volume $\left(\boldsymbol{\mu m}^{\mathbf{3}}\right)$ \\
\hline BG11 & 17 & 6 & 80.1 & 1814.9 \\
DIWW 100\% & 14 & 13 & 142.9 & 2666.9 \\
\hline
\end{tabular}

These values show an increase of 1.78 and 1.46 times the cell area and volume in the treatments compared to the control, respectively.

\subsection{Nutrient Removal}

Microalgae have the ability to use nutrients from wastewater as culture substrates for growth, which gives an additional advantage to growing these microorganisms for wastewater treatment.

In the cultivation of Scenedesmus sp. with $100 \%$ dairy industry wastewater, removal percentages of $88.4 \%$ for total nitrogen, $97.1 \%$ for $\mathrm{PO}_{4}{ }^{3-}$, and $89.3 \%$ for COD were obtained (Table 5).

Table 5. Nutrient assimilation and chemical oxygen demand (COD) removal percentages for Scenedesmus sp. grown in $100 \%$ dairy industry wastewater.

\begin{tabular}{cccc}
\hline Parameter & Initial Concentration & Final Concentration & Removal (\%) \\
\hline $\mathrm{TN}(\mathrm{mM})$ & 20.80 & 2.41 & 88.41 \\
$\mathrm{PO}_{4}{ }^{3-}(\mathrm{mM})$ & 1.67 & 0.049 & 97.07 \\
$\mathrm{COD}\left(\mathrm{mg} \mathrm{O}_{2} \mathrm{~L}^{-1}\right)$ & 3500 & 374.15 & 89.31 \\
\hline
\end{tabular}

\section{Discussion}

Wastewater as an alternative culture medium induces the modification of the biochemical composition of the biomass of microalgae and cyanobacteria, which depends on the type of sewage used since they are generally toxic environments for microalgae and can cause some sensitivity in these microorganisms. However, it has been shown that microalgae can acclimatize to a series of stress conditions such as variations in salinity, light or temperature, the influence of heavy metals, nutrient deficiency, among others [51]. Microalgae are potential biological systems for treating various wastewater sources due to their metabolic flexibility [52]. Concerning heavy metals, it has been shown that microalgae have developed mechanisms to tolerate the toxicity of these elements, which constitutes an advantage in wastewater bioremediation processes. However, this will depend on the metabolism and resistance of the strain used [53]. The wastewater sample used in this investigation contains heavy metals concentrations within the permissible range except for mercury, which exceeds the limit by 44.5 times, as observed in Table 6.

Table 6. Recommended limits of heavy metals in wastewater [54,55].

\begin{tabular}{ccccc}
\hline Heavy Metal & This Research & WHO $^{\mathbf{1}}$ & NEMA $^{\mathbf{2}}$ & EPA $^{\mathbf{3}}$ \\
\hline $\mathrm{As}\left(\mathrm{mg} \mathrm{L}^{-1}\right)$ & 0.0060 & 0.010 & $\mathrm{NM}^{*}$ & 0.05 \\
$\mathrm{Cd}\left(\mathrm{mg} \mathrm{L}^{-1}\right)$ & 0.00047 & 0.003 & 0.01 & 0.01 \\
$\mathrm{Hg}\left(\mathrm{mg} \mathrm{L}^{-1}\right)$ & 0.0890 & 0.001 & 0.005 & 0.00003 \\
$\mathrm{~Pb}\left(\mathrm{mg} \mathrm{L}^{-1}\right)$ & 0.0001 & 0.010 & 0.01 & 0.006 \\
\hline
\end{tabular}

${ }^{1}$ World Health Organization, ${ }^{2}$ National Environment Management Authority of Kenya, ${ }^{3}$ Environmental Protection Agency of United States. NM*: not mentioned. 
The results obtained in this research show that agro-industrial wastewater can be used as a culture substrate for the microalgae Scenedesmus sp., which is reflected in the increase in cell density similar to that obtained with the standard culture medium. This result is consistent with the research by Nagi et al. [56] and Koreiviene et al. [57], who used low initial cell concentrations and obtained an increase in cell density of up to 7.5 and 3600 times, respectively.

The growth of microalgae in dairy wastewater will depend on the metabolic capacity of the selected strains and the particular characteristics of the wastewater used as a culture substrate. Lu et al. [58] evaluated the growth of Chlorella sp. in wastewater from raw dairy products and observed after eight days that this strain is capable of adapting rapidly to the effluent used. This is evidenced in the thirteen-fold increase in the biomass concentration compared to the initial inoculum. This result agrees with what was obtained by Marazzi et al. [59], who demonstrated that dairy wastewater from whey processing, characterized by high contents of COD and organic nitrogen, allows the growth of Scenedesmus acuminatus, with percentages of removal of nutrients greater than $65 \%$. Similar results obtained with other strains show that the native microalgae Scenedesmus sp. (RJ 3009) can adapt to dairy wastewater as an alternative growth medium, sustainable and profitable for culture at scale.

The growth rate of these microorganisms grown in agro-industrial wastewater generally correlates with the concentration of $\mathrm{N}$ and $\mathrm{P}$ in the wastewater [60]. The specific growth rate in our research was similar in cultures maintained with DIWW and cultures with standard medium (BG11). This result agrees with the work carried out by Jebali et al. [61] and Sweiss [62]. They demonstrated that strains that adapt to wastewater have better growth and show a high percentage of reduction in wastewater organic load. Hena et al. [63] used isolated strains from urban wastewater and evaluated their cultivation in municipal wastewater from a treatment plant, with Scenedesmus sp. LS40 obtained a specific growth rate of 0.468 day $^{-1}$ and a lipid accumulation percentage of $29.4 \%$ in dry biomass, growth results similar to this investigation, but with lower lipid concentrations than our research. Ling et al. [64] isolated the microalgae Scenedesmus obliquus from wastewater from a dairy farm and later used it in municipal wastewater treatment, where they obtained a maximum specific growth rate of $0.48 \mathrm{day}^{-1}$ with high removal percentages of ammonium and phosphate; however, the lipid content only reached $19.7 \%$ of the dry weight of the biomass. Wu et al. [65] evaluated the culture of Scenedesmus sp. in urban wastewater with different $\mathrm{N}: \mathrm{P}$ ratios obtaining values for the specific growth rate in the range of 0.14-0.62 day $^{-1}$; the highest values for this parameter were with high N:P ratios.

Productivity is also influenced by the microalgal strain used and the characteristics of the environment where it grows (Table 7). Hena et al. [66] reported productivity of $0.20 \mathrm{~g} \mathrm{~L}^{-1}$ day $^{-1}$ for Chlorella saccharophila and $0.21 \mathrm{~g} \mathrm{~L}^{-1}$ day $^{-1}$ for Scenedesmus sp. in untreated wastewater from dairy farms, with lipid concentrations of 21.82 and $13.64 \%$, respectively. Kuo et al. [67] cultivated Chlorella sp. in different concentrations of piggery wastewater (PWW) $(0 \%, 25 \%, 50 \%, 75 \%$, and $100 \%)$ which was previously sterilized and centrifuged. They obtained productivity of $0.68 \mathrm{~g} \mathrm{~L}^{-1} \mathrm{day}^{-1}$ in the treatment with $100 \%$ PWW; however, the highest production of lipids was at $25 \%$ PWW, with $29.3 \%$. In a more extensive study, Jeong and Jang [68] evaluated the lipid production of ten chlorophyte microalgae isolated from wastewater and an urban water treatment plant. The microalgae were cultivated in the Bold basal medium, and results showed a varied concentration of lipids. The lowest lipid content was $24.0 \%$ in Micractinium pusillum and the highest with $46.9 \%$ in Chlorella sorokiniana. We must emphasize that the lipid concentrations of Scenedesmus sp. grown in DIWW in our work are significantly higher $(50.78 \%)$ than the studies mentioned above. This last characteristic, added to the high productivity obtained $\left(1.75 \mathrm{~g} \mathrm{~L}^{-1}\right.$ day $\left.^{-1}\right)$, makes these microalgae an interesting alternative biodiesel production source. 
Table 7. Biomass productivity and lipid concentration of microalgae grown in wastewater.

\begin{tabular}{|c|c|c|c|}
\hline Microalgal Strain & Productivity $\left(\mathrm{g} \mathrm{L}^{-1}\right.$ day $^{-1}$ ) & Lipid Concentrations (\%) & Reference \\
\hline Chlorella saccharophila & 0.20 & 21.82 & \multirow{2}{*}{ Hena et al. [66] } \\
\hline Scenedesmus sp. & 0.21 & 13.64 & \\
\hline Chlorella sp. & 0.68 & $29.3 \%$ & Kuo et al. [67] \\
\hline Chlorella sorokiniana & - & $46.9 \%$ & Jeong and Jang [68] \\
\hline Scenedesmus sp. & 1.75 & $50.78 \%$ & This research \\
\hline
\end{tabular}

Scenedesmus has been widely studied concerning its production and composition of biomass in cultures with wastewater. Shen et al. [69] evaluated the municipal wastewater treatment (MWW) with S. obliquus, reaching a productivity of $0.578 \mathrm{~g} \mathrm{~L}^{-1} \mathrm{~d}^{-1}$, and the composition of the dry biomass presented $19 \%$ of proteins, $64 \%$ of carbohydrates, and $17 \%$ of lipids. However, Ansari et al. [70] with the same species and wastewater (S. obliquus, MWW), obtained lower productivity, $0.085 \mathrm{~g} \mathrm{~L}^{-1} \mathrm{~d}^{-1}$, and the composition of the dry biomass was $28.5 \%$ protein, $27.5 \%$ carbohydrates, and $26.5 \%$ lipids. The difference between both studies is that Shen et al. supplemented the culture with $\mathrm{CO}_{2}$, and it is due to this that they had a high productivity, and percentage of carbohydrates (64\%).

The results in terms of productivity and biomass composition of Scenedesmus spp. grown with standard media are varied. Thus, regarding S. obliquus grown in a one-liter PBR, with the standard Detmer culture medium, the cultures were supplemented with $2.5 \% \mathrm{CO}_{2}$, the maximum productivity reached was $0.573 \mathrm{~g} \mathrm{~L}^{-1} \mathrm{~d}^{-1}$, and the composition of the biomass presented the following characteristics: $35.48 \%, 38.81 \%$, and $8.94 \%$ for proteins, carbohydrates and lipids, respectively [71]. However, for $S$. obtusiusculus grown in the same system (PBR), with the standard culture medium BG11, with the supplement of $\mathrm{CO}_{2} 5.0 \%$, the cultures reached productivity of $0.500 \mathrm{~g} \mathrm{~L}^{-1} \mathrm{~d}^{-1}$, and the composition of the biomass presented the following profile: proteins $25 \%$, carbohydrates $28 \%$, and lipids $38 \%$ [ 72 ].

The content and composition of fatty acids in microalgae are influenced by culture conditions, directly affecting the concentration of FAMEs. In general, the composition of the fatty acids of microalgae grown in wastewater shows the dominance of unsaturated fatty acids (monounsaturated, polyunsaturated) and, in less concentration, saturated fatty acids. This is evidenced in investigations where $77 \%$ and $23 \%$ of unsaturated and saturated esters [73] have been obtained in a culture of Chlorella vulgaris in dairy wastewater effluents, $63 \%$ and $37 \%$ [66] with a microalgae-cyanobacteria consortium cultivated in wastewater from a dairy farm, 51\% and 42\% [74] with Scenedesmus ecornis using fertilizer plant wastewater as culture substrate, $51 \%$ and $44 \%$ [75] with Scenedesmus cultivated in $100 \%$ synthetic urban wastewater, and $65 \%$ and $29 \%$ obtained in this research (Scenedesmus sp.) in $100 \%$ DIWW. Good quality biodiesel is mainly composed of C14-C18 fatty acids, as obtained in this study where short-chain fatty acids reached high concentrations, represented by palmitic, linoleic, and linolenic acids. However, European Standard 14214 [76] determined that for quality biodiesel for vehicles, the maximum concentration of linolenic acid (C18:3) is $12 \%$, a value that is two times lower than that obtained with Scenedesmus sp. (RJ 3009). Most of the microalgae oils do not comply with this standard due to polyunsaturated fatty acids in a higher proportion than the degree of unsaturation of this type of lipid compound. Despite this inconvenience, studies affirm that establishing different growing conditions, partial catalytic hydrogenation processes of the oil, mixtures with lipid substances from other raw materials and lipid extraction from wet biomass can reduce oxidative stability problems, inadequate cold flow control, and unsaturation levels, making the use of microalgal oil as a source of biodiesel viable $[77,78]$.

The microalgae Scenedesmus sp. can grow in various types of sewage and accumulate lipids intracellularly, and this was verified in our research with the high values of productivity and lipid concentration obtained in the cultures maintained in the DIWW. However, the morphology of cells is altered by their tendency to accumulate lipids and carbohydrates in organelles as energy stores [79]. These morphological changes are evidenced in the increase in the surface-volume values, where the cells become spherical for better absorption of light and nutrients [80] (Figure 7). 


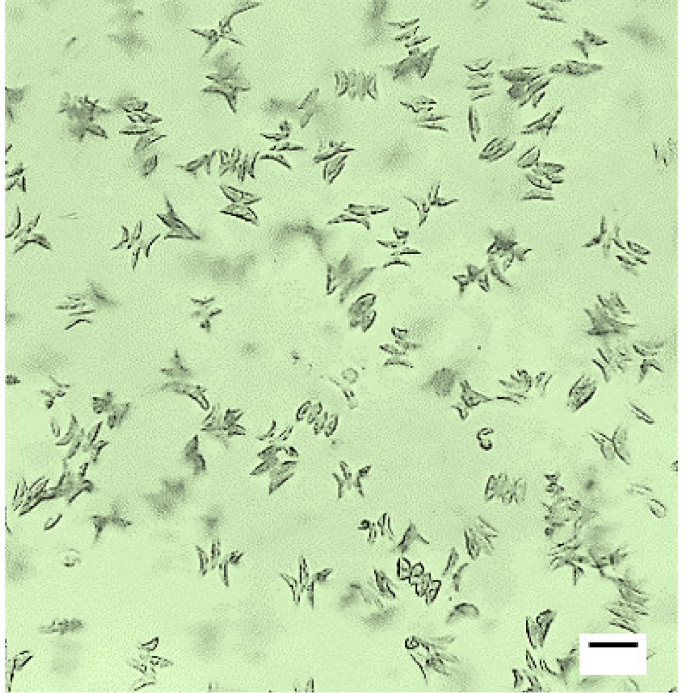

(a)

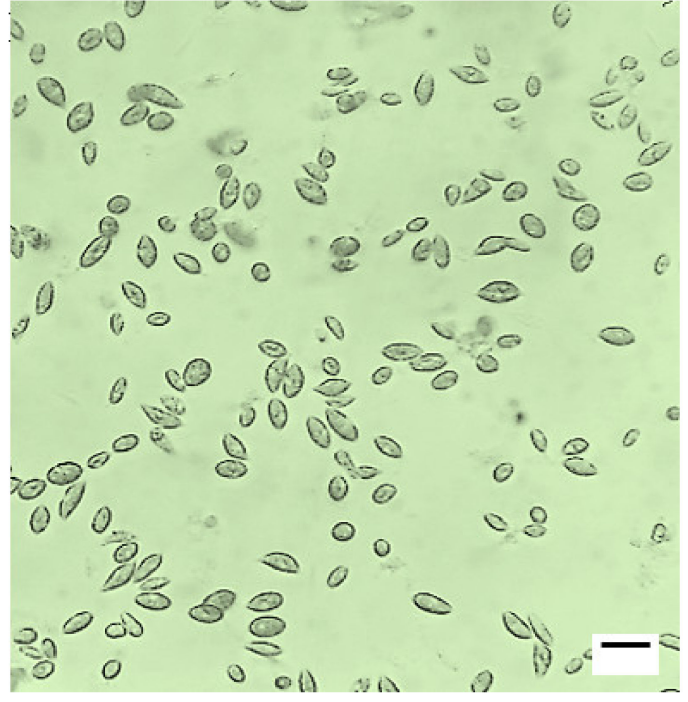

(b)

Figure 7. Light microscopes images (40x) of Scenedesmus sp. in different culture conditions (a) Scenedesmus sp. in BG11 standard culture medium. (b) Scenedesmus sp. in dairy industry wastewater [81]. Scale: $20 \mu \mathrm{m}$.

It is proven that microalgae can increase biomass production, while greater availability of nutrients exists in the environment. Tuantet et al. [82] used a mixture of male and female human urine characterized by high nitrogen and phosphorus contents as a culture substrate for Chlorella sorokiniana. The authors obtained productivity of $9.3 \mathrm{~g} \mathrm{~L}^{-1}$ day $^{-1}$ and removal efficiencies of $60 \%$ for nitrogen and $100 \%$ for phosphorus. The productivity value achieved is due to the high concentrations of nitrogen and phosphorus in the urine used, promoting the growth of these microorganisms.

The content of organic compounds in agro-industrial wastewater, availability of nutrients, and cultivation conditions, influence the composition of the biomass of the microalgae cultivated in this type of substrate $[83,84]$. In this research, cultivation in the wastewater of the dairy industry influenced the metabolism of Scenedesmus sp., directing the flow of carbon fixed by photosynthesis to the synthesis of lipids in higher concentration ( $50.78 \%$ lipids) compared to the cultures maintained with the standard culture medium (35.08\%). These results are similar to those obtained by Shen et al. [85], where they used the microalgae Botryococcus sp. isolated from a domestic wastewater treatment plant. This microalga was cultivated in synthetic wastewater, where it obtained a lipid production of $61.7 \%$ and nutrient removal of $64.5 \%$ of nitrogen and $89.8 \%$ of phosphorus. Botryococcus sp. obtained a high concentration of lipids explained by the heterotrophic culture conditions to which it was subjected (glucose $10 \mathrm{~g} \mathrm{~L}^{-1}$, absence of light). However, the nutrient removal efficiency was lower compared to our research.

Shen et al. [86] used wastewater from a pig farm with the previous filtration of solid particles to cultivate a different microalgae strain in lipid production. The Chlorella vulgaris microalgae obtained a lipid concentration of $38.6 \%$ and high percentages of nutrient removal (96\% nitrogen removal and $99.8 \%$ phosphorus removal). These results suggest that the microalgae used has a high capacity for removing nutrients from wastewater for the production of biofuels; however, the pre-treatment applied reduces the profitability of the process and increases production costs.

The efficiency of nutrient removal by microalgae is directly related to their ability to use inorganic nitrogen and phosphorus for their growth [87], which will depend on the strain used and the availability of nutrients in the wastewater. In the present investigation, nutrient removal percentages higher than 85\% were obtained for nitrogen and phosphorus, making the use of Scenedesmus sp. viable for the treatment of this type of effluent. These results can be compared with those obtained by Gupta et al. [88], who used the Scenedesmus obliquus strain in different concentrations of municipal wastewater previously filtered and aerated for eight hours, obtaining removal percentages of $98 \%$ nitrogen and $97 \%$ phosphorus 
at 15 days when cultivating the microalgae at $100 \%$ sewage; however, lipid production only reached $23 \%$ of the biomass composition. Although the strain used reached percentages of nutrient removal efficiency similar to those of the present investigation, a pre-treatment was carried out on the wastewater used, which reduces its profitability in possible industrial applications.

On the other hand, the chemical oxygen demand is an important parameter related to the amount of organic matter susceptible to oxidation processes, closely related to eutrophication and contamination in the environment. Ding et al. [89] using Chlorella culture with different percentages of milk residual water $(5 \%, 10 \%, 20 \%$ ) obtained removal rates of $84.2 \%, 87.9 \%$, and $89.7 \%$ of COD, while Randi et al. [90] in the cultivation of Chlorella vulgaris and Anabaena ambigua in previously filtered dairy effluents obtained removal percentages of $96.36 \%$ and $95.9 \%$, respectively. This is similar to that reported by Brar et al. [91], which shows a removal of $87.5 \%$ in cultures of C. pyrenoidosa in $75 \%$ of dairy wastewater; however, this percentage of COD reduction is achieved after 25 days of culture. The result agrees with that obtained with Scenedesmus sp., evidencing that microalgae can reduce COD in agro-industrial effluents. However, the present work shows advantages when using $100 \%$ of the residual, with high COD concentrations and no pretreatment process, as a cultivation substrate. It is worth mentioning that a high COD removal can be obtained by using microalgal consortia, increasing the efficiency of nutrient assimilation, as reported by Hena et al. [63]. They observed that the use of a consortium of microalgae and cyanobacteria represented by Chlorella, Ankistrodesmus, Chlamydomonas, and Scenedesmus reached $98.8 \%$ COD removal.

\section{Conclusions}

Agro-industrial wastewater is a sustainable alternative for the cultivation of microalgae for bioenergetic applications to use the nutrients present in these substrates for the accumulation of energy compounds and, at the same time, purify them, avoiding contamination of freshwater sources.

The native microalgae Scenedesmus can be grown in dairy industry wastewater with similar culture results to standard BG11 medium concerning productivity and growth. Scenedesmus sp. could increase its concentration of lipids in this culture system without presenting a significant decrease in cell density, diverting the carbon flux to synthesize these compounds.

The cultivation of Scenedesmus sp. in agro-industrial wastewater constitutes a profitable and sustainable biotechnological alternative for obtaining biomass with the high added value of commercial interest.

Author Contributions: X.Á., I.M., and M.-E.V. conceived and designed the experiments; I.M., A.C., and M.-E.V. performed the experiments; X.Á., I.M., and M.-E.V. analyzed the data; I.M. and X.Á. wrote the paper. All authors have read and agreed to the published version of the manuscript.

Funding: This work has been supported by the Internal Competitive Fund (FCI) of the University of Guayaquil, through resolution No. R-CIFI-UG-S011-233-21-06-2019.

Acknowledgments: We thank the team of the Microalgae and Cyanobacteria Biotechnology area for the technical support during the project. The wastewater from the dairy industry was kindly provided by Gean Rossi (Quito), Ecuador.

Conflicts of Interest: The authors declare no conflict of interest.

\section{References}

1. Emsbo-Mattingly, S.D.; Litman, E. Polycyclic aromatic hydrocarbon homolog and isomer fingerprinting. In Standard Handbook Oil Spill Environmental Forensics, 2nd ed.; Stout, S., Wang, Z., Eds.; Academic Press: Cambridge, UK, 2016; pp. 255-312. [CrossRef]

2. Kiang, Y. Fuel Property Estimation and Combustion Process Characterization. Conventional Fuels, Biomass, Biocarbon, Waste Fuels, Refuse Derived Fuel, and Other Alternative Fuels, 1st ed.; Academic Press: Cambridge, UK, 2018.

3. Gautam, P.; Kumar, S.; Lokhandwala, S. Energy-Aware Intelligence in Megacities. In Current Developments in Biotechnology and Bioengineering. Waste Treatment Processes for Energy Generation, 1st ed.; Kumar, S., Kumar, R., Pandey, A., Eds.; Elsevier: Amsterdam, The Netherlands, 2019; pp. 211-238. [CrossRef] 
4. Howarth, R.W.; Santoro, R.; Ingraffea, A. Methane and the greenhouse-gas footprint of natural gas from shale formations. Clim. Chang. 2011, 106, 679-690. [CrossRef]

5. Shafiee, S.; Topal, E. When will fossil fuel reserves be diminished? Energy Policy 2009, 37, 181-189. [CrossRef]

6. Canté, F. Renta negativa y decrecimiento económico. Apunt. CENES 2018, 37, 53-74. [CrossRef]

7. Rather, M.A.; Bano, P. Third Generation Biofuels: A Promising Alternate Energy Source. In Integrating Green Chemistry and Sustainable Engineering; Wiley \& Sons: Hoboken, NJ, USA, 2019; pp. 1-21.

8. Datta, A.; Hossain, A.; Roy, S. An Overview on Biofuels and Their Advantages and Disadvantages. Asian J. Chem. 2019, 31, 1851-1858. [CrossRef]

9. International Energy Agency. World Energy Outlook 2007: China and India Insights; OECD Publishing: Paris, France, 2007. [CrossRef]

10. Naqvi, M.; Yan, J. First-Generation Biofuels. In Handbook of Clean Energy Systems; Wiley \& Sons: Hoboken, NJ, USA, 2015; Volume 1, pp. 1-18.

11. Raghavendra, H.; Mishra, S.; Upashe, S.P.; Floriano, J.F. Research and Production of Second-Generation Biofuels. In Bioprocessing for Biomolecules Production, 1st ed.; Molina, G., Gupta, V., Singh, B., Gathergood, N., Eds.; Wiley \& Sons: Hoboken, NJ, USA, 2019; pp. 383-400.

12. Richmond, A. Biological Principles of Mass Cultivation. In Handbook of Microalgae Culture: Biotechnology and Applied Phycology, 1st ed.; Richmond, A., Ed.; Blackwell Publishing: Hoboken, NJ, USA, 2004; pp. 125-177.

13. Chisti, Y. Biodiesel from microalgae beats bioethanol. Trends Biotechnol. 2008, 26, 126-131. [CrossRef]

14. Moravvej, Z.; Makarem, M.A.; Rahimpour, M.R. The fourth generation of biofuel. In Second and Third Generation of Feedstocks, 1st ed.; Basile, A., Dalena, F., Eds.; Elsevier: Amsterdam, The Netherlands; Oxford, UK; Cambridge, MA, USA, 2019; pp. 557-597. [CrossRef]

15. Abdullah, B.; Muhammad, S.A.F.S.; Shokravi, Z.; Ismail, S.; Kassim, K.A.; Mahmood, A.N.; Aziz, M.A. Fourth generation biofuel: A review on risks and mitigation strategies. Renew. Sustain. Energy Rev. 2019, 107, 37-50. [CrossRef]

16. Randrianarison, G.; Ashraf, M.A. Microalgae: A potential plant for energy production. Geol. Ecol. Landsc. 2017, 1, 104-120. [CrossRef]

17. Zullaikah, S.; Utomo, A.T.; Yasmin, M.; Ong, L.K.; Ju, Y.-H. Ecofuel conversion technology of inedible lipid feedstocks to renewable fuel. In Advances in Eco-Fuels for a Sustainable Environment, 1st ed.; Kalam Azad, A., Ed.; Woodhead Publishing: Cambridge, MA, USA, 2019; pp. 237-276.

18. Chapman, R.L. Algae: The world's most important "plants"-An introduction. Mitig. Adapt. Strat. Glob. Chang. 2013, 18, 5-12. [CrossRef]

19. Nascimento, M.D.; Rizza, L.S.; Di Palma, A.A.; Dublan, M.D.L.A.; Salerno, G.L.; Rubio, L.M.; Curatti, L. Cyanobacterial biological nitrogen fixation as a sustainable nitrogen fertilizer for the production of microalgal oil. Algal Res. 2015, 12, 142-148. [CrossRef]

20. Wang, Q.; Lu, Y.; Xin, Y.; Wei, L.; Huang, S.; Xu, J. Genome editing of model oleaginous microalgae Nannochloropsis spp. by CRISPR/Cas9. Plant J. 2016, 88, 1071-1081. [CrossRef]

21. Choong, Y.J.; Yokoyama, H.; Matsumura, Y.; Lam, M.K.; Uemura, Y.; Dasan, Y.K.; Kadir, W.N.A.; Lim, J.W. The potential of using microalgae for simultaneous oil removal in wastewater and lipid production. Int. J. Environ. Sci. Technol. 2020, 17, 2755-2766. [CrossRef]

22. Li, J.; Liu, Y.; Cheng, J.J.; Mos, M.; Daroch, M. Biological potential of microalgae in China for biorefinery-based production of biofuels and high value compounds. New Biotechnol. 2015, 32, 588-596. [CrossRef] [PubMed]

23. Zhu, L.; Li, Z.H.; Hiltunen, E. Strategies for Lipid Production Improvement in Microalgae as a Biodiesel Feedstock. BioMed Res. Int. 2016, 2016, 8792548. [CrossRef] [PubMed]

24. Aratboni, H.A.; Rafiei, N.; Garcia-Granados, R.; Alemzadeh, A.; Morones-Ramirez, J.R. Biomass and lipid induction strategies in microalgae for biofuel production and other applications. Microb. Cell Factories 2019, 18, 1-17. [CrossRef] [PubMed]

25. Komolafe, O.; Orta, S.B.V.; Monje-Ramirez, I.; Noguez, I.Y.; Harvey, A.P.; Ledesma, M.T.O. Biodiesel production from indigenous microalgae grown in wastewater. Biores. Technol. 2014, 154, 297-304. [CrossRef]

26. Lackner, M. 3rd-Generation Biofuels: Bacteria and Algae as Sustainable Producers and Converters. In Handbook of Climate Change Mitigation and Adaptation, 2nd ed.; Chen, W.Y., Suzuki, T., Lackner, M., Eds.; Springer: Berlin, Germany, 2016; pp. 3173-3210. 
27. Álvarez, X.; Otero, A. Nutrient removal from the centrate of anaerobic digestion of high ammonium industrial wastewater by a semi-continuous culture of Arthrospira sp. and Nostoc sp. PCC 7413. Environ. Biol. Fishes 2020, 7413, 1-10. [CrossRef]

28. Benemann, J.; Vanolst, J.; Massingill, M.; Carlberg, J.; Weissman, J.; Brune, D. The controlled eutrophication process: Using Microalgae for $\mathrm{CO}_{2}$ utilization and agricultural fertilizer recycling. In Proceedings of the 7th International Conference on Greenhouse Gas Control Technologies, Vancouver, BC, Canada, 5-9 September 2004; pp. 1433-1438. [CrossRef]

29. Molazadeh, M.; Ahmadzadeh, H.; Pourianfar, H.R.; Lyon, S.; Rampelotto, P.H. The Use of Microalgae for Coupling Wastewater Treatment with $\mathrm{CO}_{2}$ Biofixation. Front. Bioeng. Biotechnol. 2019, 7, 42. [CrossRef]

30. Allen, M.M. Simple Conditions for Growth of Unicellular Blue-Green Algae on Plates. J. Phycol. 1968, 4, 1-4. [CrossRef]

31. Álvarez, X. Modulación de la Producción y Caracterización Estructural de los Exopolisacáridos en Cianobacterias Diazotróficas, y Estudio de su Utilización para el Tratamiento del Digestato Líquido de la Digestión Anaeróbica de Efluente Efluentes de una Procesadora de Pescado. Ph.D. Thesis, Universidade de Santiago de Compostela, Santiago de Compostela, Spain, 2016.

32. International Council for Standardization in Haematology. Recommended Methods for the Visual Determination of White Blood Cell Count and Platelet Counts, 1st ed.; World Health Organization: Geneva, Switzerland, 2000.

33. Arredondo, B.; Voltolina, D.; Zenteno, T.; Arce, M.; Gómez, G. Métodos y Herramientas Analíticas en la Evaluación de la Biomasa Microalgal, 2nd ed.; Centro de Investigaciones Biológicas del Noroeste: La Paz, Mexico, 2017.

34. Zhu, C.J.; Lee, Y.K. Determination of biomass dry weight of marine microalgae. Environ. Biol. Fishes 1997, 9 , 189-194. [CrossRef]

35. Dubois, M.; Gilles, K.A.; Hamilton, J.K.; Rebers, P.A.; Smith, F. Colorimetric Method for Determination of Sugars and Related Substances. Anal. Chem. 1956, 28, 350-356. [CrossRef]

36. Lowry, O.H.; Rosebrough, N.J.; Farr, A.L.; Randall, R.J. Protein measurement with the Folin phenol reagent. J. Biol. Chem. 1951, 193, 265-275. [PubMed]

37. Herbert, D.; Phipps, P.; Strange, R. Chapter III Chemical Analysis of Microbial Cells. Methods Microbiol. 1971, 5, 209-344. [CrossRef]

38. Bligh, E.G.; Dyer, W.J. A Rapid Method of Total Lipid Extraction and Purification. Can. J. Biochem. Physiol. 1959, 37, 911-917. [CrossRef] [PubMed]

39. Marsh, J.B.; Weinstein, D.B. Simple charring method for determination of lipids. J. Lipid Res. 1966, 7, 574-576.

40. AOAC. Official Methods of Analysis, 18th ed.; Association of Official Analytical Chemists: Rockville, MD, USA, 2005.

41. AOAC. Official Methods of Analysis, 17th ed.; Association of Official Analytical Chemists: Rockville, MD, USA, 2000.

42. AOAC. Official Methods of Analysis, 16th ed.; Association of Official Analytical Chemists: Washington, DC, USA, 1995.

43. D'Elia, C.F.; Steudler, P.A.; Corwin, N. Determination of total nitrogen in aqueous samples using persulfate digestion1. Limnol. Oceanogr. 1977, 22, 760-764. [CrossRef]

44. Tandon, H.L.S.; Cescas, M.P.; Tyner, E.H. An Acid-Free Vanadate-Molybdate Reagent for the Determination of Total Phosphorus in Soils. Soil Sci. Soc. Am. J. 1968, 32, 48-51. [CrossRef]

45. APHA. Standard Methods for the Examination of Water and Wastewater, 23rd ed.; American Public Health Association: Washington, DC, USA, 2017.

46. Evans, S.J.; Johnson, M.S.; Leah, R.T. Determination of mercury in fish tissue: A rapid automated technique for routine analysis. Varian Instrum. Work 1986, 60, 1-6.

47. AOAC. Official Methods of Analysis, 21st ed.; Association of Official Analytical Chemists: Rockville, MD, USA, 2019.

48. Deaker, M.; Maher, W. Determination of arsenic in arsenic compounds and marine biological tissues using low volume microwave digestion and electrothermal atomic absorption spectrometry. J. Anal. At. Spectrom. 1999, 14, 1193-1207. [CrossRef]

49. Chen, M.; Li, J.; Dai, X.; Sun, Y.; Chen, F. Effect of phosphorus and temperature on chlorophyll a contents and cell sizes of Scenedesmus obliquus and Microcystis aeruginosa. Limnology 2010, 12, 187-192. [CrossRef] 
50. Cheirsilp, B.; Srinuanpan, S.; Mandik, Y. Efficient harvesting of microalgal biomass and direct conversion of microalgal lipids into biodiesel. In Microalgae Cultivation for Biofuels Production, 1st ed.; Yousuf, A., Ed.; Academic Press: Cambridge, UK, 2010; Volume 1, pp. 83-96. [CrossRef]

51. Osundeko, O.; Dean, A.P.; Davies, H.; Pittman, J.K. Acclimation of Microalgae to Wastewater Environments Involves Increased Oxidative Stress Tolerance Activity. Plant Cell Physiol. 2014, 55, 1848-1857. [CrossRef]

52. Wollmann, F.; Dietze, S.; Ackermann, J.; Bley, T.; Walther, T.; Steingroewer, J.; Krujatz, F. Microalgae wastewater treatment: Biological and technological approaches. Eng. Life Sci. 2019, 19, 860-871. [CrossRef] [PubMed]

53. Kumar, K.S.; Dahms, H.-U.; Won, E.-J.; Lee, J.-S.; Shin, K.-H. Microalgae-A promising tool for heavy metal remediation. Ecotoxicol. Environ. Saf. 2015, 113, 329-352. [CrossRef]

54. Kinuthia, G.K.; Ngure, V.; Beti, D.; Lugalia, R.; Wangila, A.; Kamau, L. Levels of heavy metals in wastewater and soil samples from open drainage channels in Nairobi, Kenya: Community health implication. Sci. Rep. 2020, 10, 1-13. [CrossRef]

55. Shakoor, M.B.; Bibi, I.; Niazi, N.K.; Shahid, M.; Nawaz, M.F.; Farooqi, A.; Naidu, R.; Rahman, M.M.; Murtaza, G.; Lüttge, A. The evaluation of arsenic contamination potential, speciation and hydrogeochemical behaviour in aquifers of Punjab, Pakistan. Chemosphere 2018, 199, 737-746. [CrossRef]

56. Nagi, M.; He, M.; Li, D.; Gebreluel, T.; Cheng, B.; Wang, C. Utilization of tannery wastewater for biofuel production: New insights on microalgae growth and biomass production. Sci. Rep. 2020, 10, 1-14. [CrossRef]

57. Koreivienė, J.; Valčiukas, R.; Karosienė, J.; Baltrènas, P. Testing of Chlorella/Scenedesmus Microalgae Consortia for Remediation of Wastewater, $\mathrm{CO}_{2}$ Mitigation and Algae Biomass Feasibility for Lipid Production. J. Environ. Eng. Landsc. Manag. 2014, 22, 105-114. [CrossRef]

58. Lu, W.; Wang, Z.; Wang, X.; Yuan, Z. Cultivation of Chlorella sp. using raw dairy wastewater for nutrient removal and biodiesel production: Characteristics comparison of indoor bench-scale and outdoor pilot-scale cultures. Biores. Technol. 2015, 192, 382-388. [CrossRef]

59. Marazzi, F.; Bellucci, M.; Fantasia, T.; Ficara, E.; Mezzanotte, V. Interactions between Microalgae and Bacteria in the Treatment of Wastewater from Milk Whey Processing. Water 2020, 12, 297. [CrossRef]

60. Whitton, R.; Le Mével, A.; Pidou, M.; Ometto, F.; Villa, R.; Jefferson, B. Influence of microalgal N and P composition on wastewater nutrient remediation. Water Res. 2016, 91, 371-378. [CrossRef]

61. Jebali, A.; Acién, F.; Gómez, C.; Fernández-Sevilla, J.; Mhiri, N.; Karray, F.; Dhouib, A.; Molina-Grima, E.; Sayadi, S. Selection of native Tunisian microalgae for simultaneous wastewater treatment and biofuel production. Biores. Technol. 2015, 198, 424-430. [CrossRef]

62. Sweiss, M. Microalgas para Tratamiento de Aguas Residuales y Producción de Biomasa Desde Bioprospección Hasta Biotecnología. Ph.D. Thesis, Universidad de Bath, Inglaterra, UK, 2017.

63. Hena, S.A.; Abida, N.; Tabassum, S. Screening of facultative strains of high lipid producing microalgae for treating surfactant mediated municipal wastewater. RSC Adv. 2015, 5, 98805-98813. [CrossRef]

64. Ling, Y.; Sun, L.-P.; Wang, S.-Y.; Lin, C.S.K.; Sun, Z.; Zhou, Z.-G. Cultivation of oleaginous microalgae Scenedesmus obliquus coupled with wastewater treatment for enhanced biomass and lipid production. Biochem. Eng. J. 2019, 148, 162-169. [CrossRef]

65. Wu, Y.-H.; Li, X.; Yu, Y.; Hu, H.-Y.; Zhang, T.-Y.; Li, F.-M. An integrated microalgal growth model and its application to optimize the biomass production of Scenedesmus sp. LX1 in open pond under the nutrient level of domestic secondary effluent. Biores. Technol. 2013, 144, 445-451. [CrossRef] [PubMed]

66. Hena, S.; Fatimah, S.; Tabassum, S. Cultivation of algae consortium in a dairy farm wastewater for biodiesel production. Water Res. Ind. 2015, 10, 1-14. [CrossRef]

67. Kuo, C.-M.; Chen, T.-Y.; Lin, T.-H.; Kao, C.-Y.; Lai, J.-T.; Chang, J.-S.; Lin, C.-S. Cultivation of Chlorella sp. GD using piggery wastewater for biomass and lipid production. Biores. Technol. 2015, 194, 326-333. [CrossRef]

68. Jeong, D.; Jang, A. Exploration of microalgal species for simultaneous wastewater treatment and biofuel production. Environ. Res. 2020, 188, 109772. [CrossRef]

69. Shen, Q.-H.; Jiang, J.-W.; Chen, L.-P.; Cheng, L.-H.; Xu, X.-H.; Chen, H.-L. Effect of carbon source on biomass growth and nutrients removal of Scenedesmus obliquus for wastewater advanced treatment and lipid production. Biores. Technol. 2015, 190, 257-263. [CrossRef] 
70. Ansari, F.A.; Ravindran, B.; Gupta, S.K.; Nasr, M.; Rawat, I.; Bux, F. Techno-economic estimation of wastewater phycoremediation and environmental benefits using Scenedesmus obliquus microalgae. J. Environ. Manag. 2019, 240, 293-302. [CrossRef]

71. Ho, S.-H.; Kondo, A.; Hasunuma, T.; Chang, J.-S. Engineering strategies for improving the $\mathrm{CO}_{2}$ fixation and carbohydrate productivity of Scenedesmus obliquus CNW-N used for bioethanol fermentation. Biores. Technol. 2013, 143, 163-171. [CrossRef]

72. Toledo-Cervantes, A.; Morales, M.; Novelo, E.; Revah, S. Carbon dioxide fixation and lipid storage by Scenedesmus obtusiusculus. Biores. Technol. 2013, 130, 652-658. [CrossRef]

73. Choi, H.-J. Dairy wastewater treatment using microalgae for potential biodiesel application. Environ. Eng. Res. 2016, 21, 393-400. [CrossRef]

74. Ambat, I.; Bec, S.; Peltomaa, E.; Srivastava, V.; Ojala, A.; Sillanpää, M. A synergic approach for nutrient recovery and biodiesel production by the cultivation of microalgae species in the fertilizer plant wastewater. Sci. Rep. 2019, 9, 1-9. [CrossRef]

75. Wang, Z.; Yao, X.-D.; Miao, M.-S.; Chen, Q.-F.; Kong, Q.; Shang, D.-W.; Yu, J.-N.; Fu, X.-M. Effects of urban wastewater dilution on growth and biochemical properties of Scenedesmus sp. Desalin. Water Treat. 2016, 57, 29363-29370. [CrossRef]

76. European Committee for Standardization. Liquid Petroleum Products_Fatty Acid Methyl Esters (FAME) for Use in Diesel Engines and Heating Applications_-Requirements and Test Methods; European Standard 14214; European Committee for Standardization: Brussels, Belgium, 2012.

77. Dijkstra, A.J. Revisiting the formation of-trans isomers during partial hydrogenation of triacylglycerol oils. Eur. J. Lipid Sci. Technol. 2006, 108, 249-264. [CrossRef]

78. Hoekman, S.K.; Broch, A.; Robbins, C.; Ceniceros, E.; Natarajan, M. Review of biodiesel composition, properties, and specifications. Renew. Sustain. Energy Rev. 2012, 16, 143-169. [CrossRef]

79. Castillo, O.S.; Torres-Badajoz, S.G.; Núñez-Colín, C.A.; Peña-Caballero, V.; Herrera, C.H.; Rodríguez-Núñez, J.R. Producción de biodiésel a partir de microalgas: Avances y perspectivas biotecnológicas. Hidrobiológica 2017, 27, 337-352.

80. Quevedo, C.; Sonia, M.; Acosta, A. Crecimiento de Scenedesmus sp. en diferentes medios de cultivo para producción de proteína microalgal. Vitae-Columbia 2008, 15, 25-31.

81. Verduga, M.E. Cultivo en Batch de Scenedesmus spp. en Aguas Residuales de Industrias Lácteas: Crecimiento, Productividad y Composición Bioquímica. Bachelor's Thesis, Universidad de Guayaquil, Guayaquil, Ecuador, 2020. Available online: http://repositorio.ug.edu.ec/bitstream/redug/48682/1/CD_TESIS_ELOIZA. pdf (accessed on 15 May 2020).

82. Tuantet, K.; Temmink, H.; Zeeman, G.; Janssen, M.; Wijffels, R.H.; Buisman, C.J. Nutrient removal and microalgal biomass production on urine in a short light-path photobioreactor. Water Res. 2014, 55, 162-174. [CrossRef]

83. Kumar, D.; Singh, B. Ankit. Phycoremediation of nutrients and valorisation of microalgal biomass: An economic perspective. In Application of Microalgae in Wastewater Treatment, 1st ed.; Gupta, S., Bux, F., Eds.; Springer: Cham, Switzerland, 2019; Volume 2, pp. 1-15. [CrossRef]

84. Choudhary, P.; Assemany, P.P.; Naaz, F.; Bhattacharya, A.; Castro, J.D.S.; Couto, E.D.A.D.C.; Calijuri, M.L.; Pant, K.K.; Malik, A. A review of biochemical and thermochemical energy conversion routes of wastewater grown algal biomass. Sci. Total. Environ. 2020, 726, 137961. [CrossRef]

85. Shen, L.; Ndayambaje, J.D.; Murwanashyaka, T.; Cui, W.; Manirafasha, E.; Chen, C.; Wang, Y.; Lu, Y. Assessment upon heterotrophic microalgae screened from wastewater microbiota for concurrent pollutants removal and biofuel production. Biores. Technol. 2017, 245, 386-393. [CrossRef]

86. Shen, Y.; Yang, T.; Zhu, W.; Zhao, Y. Wastewater treatment and biofuel production through attached culture of Chlorella vulgaris in a porous substratum biofilm reactor. Environ. Biol. Fishes 2016, 29, 833-841. [CrossRef]

87. Abdel-Raouf, N.; Al-Homaidan, A.; Ibraheem, I. Microalgae and wastewater treatment. Saudi J. Biol. Sci. 2012, 19, 257-275. [CrossRef]

88. Gupta, S.K.; Ansari, F.A.; Shriwastav, A.; Sahoo, N.K.; Rawat, I.; Bux, F. Dual role of Chlorella sorokiniana and Scenedesmus obliquus for comprehensive wastewater treatment and biomass production for bio-fuels. J. Clean. Prod. 2016, 115, 255-264. [CrossRef]

89. Ding, J.; Zhao, F.; Cao, Y.; Xing, L.; Liu, W.; Mei, S.; Li, S. Cultivation of Microalgae in Dairy Farm Wastewater Without Sterilization. Int. J. Phytoremed. 2015, 17, 222-227. [CrossRef] 
90. Rani, A.S.; Rao, H.R.V.N.G.; Kumar, A.B.; Shruthi, M. Eco-Friendly Approach for Treating Dairy Effluent and Lipid Estimation Using Microalgae. Br. Biotechnol. J. 2015, 7, 33-39. [CrossRef]

91. Brar, A.; Kumar, M.; Pareek, N. Comparative Appraisal of Biomass Production, Remediation, and Bioenergy Generation Potential of Microalgae in Dairy Wastewater. Front. Microbiol. 2019, 10, 678. [CrossRef] [PubMed]

Publisher's Note: MDPI stays neutral with regard to jurisdictional claims in published maps and institutional affiliations.

(C) 2020 by the authors. Licensee MDPI, Basel, Switzerland. This article is an open access article distributed under the terms and conditions of the Creative Commons Attribution (CC BY) license (http://creativecommons.org/licenses/by/4.0/). 